\title{
Sid Ahmed Hnini, prisionero de guerra número 4001
}

Sid Ahmed Hnini, War Prisoner number 4001

\section{Relato testimonial de Sid Ahmed Hnini}

Editado y presentado por MUSTAPHA M-LAMIN AHMED · musmola@alumni.uv.es

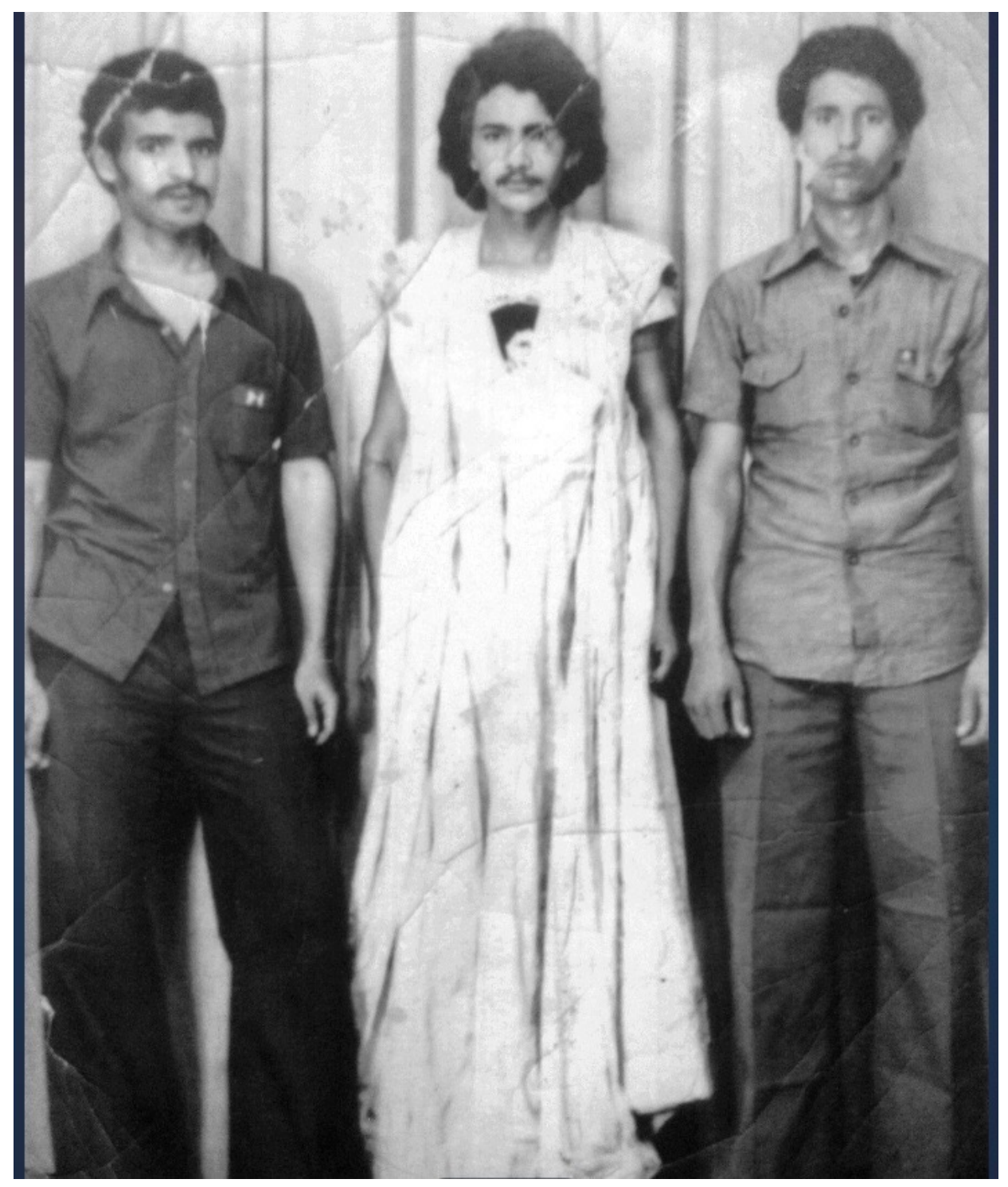

Sid Ahmed Hnini, a la izquierda. Argel 1979

Ahmed Hnini, Sid. "Sid Ahmed Hnini, prisionero de guerra 4001". Kamchatka. Revista de análisis cultural 7 (Junio 2016): 155-184 DOI: 10.7203/KAM.7.8840 ISSN: 2340-1869 
Cuando la dirección de Kamchatka. Revista de análisis cultural me prepuso la publicación de un testimonio saharauis en este dossier sobre el conflicto en el Sahara Occidental, al principio dudé de su pertinencia, pero la insistencia de la revista me convenció de la necesidad de contar con algún relato inédito de algún superviviente de la represión marroquí. Inicialmente pensamos en algún civil, pero al final nos decantamos por el testimonio de un combatiente saharaui. ¿Qué motivó esta elección?: la puesta en libertad hace 20 años de 66 prisioneros de guerra saharauis cuya existencia había negado el entonces soberano marroquí, el siniestro Hassan II, y que desde las cárceles se negaron a rendirse y entregarse al régimen ocupante, como se podrá comprobar en el testimonio que publicamos.

La dirección de la revista aceptó la propuesta sin dudarlo y valoró la posibilidad de rescatar la voz de aquellos actores históricos que abandonaron la comodidad del modo de vida colonial por la lucha contra el colonialismo y el neocolonialismo. Para ello contacté con Sid Ahmed Hnini, que estuvo 12 años en prisión después de haber sido capturado en batalla y le prepuse recoger su testimonio. Aceptó sin reservas y sin poner ninguna objeción. Aunque la formación de Sid Ahmed en las etapas de la educación obligatoria colonial fue principalmente en castellano, prefirió dar testimonio en hassaníya, el dialecto que hablamos los saharauis. Mi tarea se limitó a grabar el testimonio, transcribirlo, en primera persona del singular, traducirlo al castellano y ordenarlo posteriormente en bloques. Todo lo demás son las palabras de Sid Ahmed Hnini, prisionero de guerra número 4001, tal cual me las contó. Debido a la extensión del testimonio, me he visto obligado a resumir algunos pasajes, pero en el texto queda reflejadosegún la voluntad de Sid Ahmed, desde sus primeros años de militancia en el frente Polisario hasta su puesta en libertad.

Por último, solo me queda agradecer a Sid Ahmed su generosidad por compartir conmigo su experiencia, por facilitarme cuanta información adicional le pedí después de la primera grabación, y por haber sido tan valiente como para dar su testimonio veinte años después de su puesta en libertad. Dicho esto, dejo en manos del lector juzgar el resultado de este trabajo, cuya máxima pretensión es impedir que caigan en el olvido la lucha y el testimonio de un hombre que consagró su vida -a base de sacrificios personales y familiares, tres hijos dejó en los campamentos, con 7, 4 y menos de un año la pequeña, además de su esposa Salka Ali Salem-a la lucha por la libertad de su pueblo.

MUSTAPHA M-LAMIN AHMED 


\section{Militancia}

A principios de 1974, cuando llevaba dos años trabajando en la empresa estatal española de explotación de los fosfatos en Bucráa, Fosbucraa, empecé la militancia en el Frente Popular para la Liberación de Saguia Al-Hamra y Río de Oro (Frente Polisario). Era muy joven, como los otros compañeros de trabajo, también militantes del Frente. Además de compañeros eran mis amigos. Nuestra militancia era clandestina, totalmente secreta, ni siquiera sabíamos que otros compañeros también eran militantes. Por precaución. Siempre había colaboracionistas rondando, no se podía hablar abiertamente de la militancia. Hasta que formamos la primera célula colectiva clandestina de algunos trabajadores de Fosbucraa. La Célula el Sol, recuerdo que se llamaba, en Bucraa. A partir de ese momento fuimos sabiendo los nombres de los demás, eran todos amigos y compañeros. Recuerdo que estaban junto a mí El-Adhli (actualmente representante del Polisario en Oriente Próximo), Mohamed-Lamin Daddi (hoy Ministro de Salud en la República Saharaui), Malainin Sal-lak, Mulay Fal-li, Ali-Salem Ould El-Faqir (ahora representante del Polisario en Rusia), entre otros compañeros. Todos nosotros formábamos la célula. Empezamos las acciones con pintadas en paredes, difusión de folletos con propaganda anticolonial, en la localidad de Bucraa y también en El Aaiún. Además de eso, teníamos que diversificar nuestras acciones, compaginando pintadas y folletos con la concienciación del pueblo. Eso estaba dentro de las actividades de lucha que teníamos que hacer. Nunca abandonamos el trabajo: trabajando en la empresa del colonizador para combatirlo. El trabajo y la lucha iban de la mano mientras permaneció España en el territorio. Hasta finales del año 1975, el año del éxodo. El año de lo que los marroquíes llaman Marcha Verde. Para mí y para el resto de saharaui Marcha Negra. Ya antes de la invasión de Marruecos, empezaron a circular rumores de la entrega del territorio saharaui por España a Marruecos y Mauritania. Hubo protestas. La gente empezó a rebelarse cuando empezó a darse cuenta de la inminencia de la invasión. También hubo huelgas en Fosbucraa. Y sabotaje: la cinta transbordadora de fosfatos fue quemada por otro grupo de compañeros de Fosbucraa, posteriormente detenidos por el gobierno español. Algunos de ellos siguen viven, como Moulud Deidi o Mohamed Akeik.

\section{Éxodo hacia el este}

Cuando empezó la invasión, decidimos partir hacia el este. Lo hicimos poco antes de la entrada del ejército marroquí en El Aaiún. Justo cuando llegó el nuevo gobernador marroquí, Bensouda, el primer gobernador de El Aaiún desde que fue ocupado el territorio, decidimos marcharnos. Éramos un grupo de 20 personas, o un poco más. Alquilamos tres coches Land-Rover. Nuestro destino era Guelta, en el sureste del territorio saharaui, cerca de la frontera con Mauritania. Dormimos una noche antes de llegar a Guelta, no sabría decir dónde exactamente, porque ninguno de nosotros conocía bien el terreno. Los 
conductores sí conocían muy bien el terreno, pero nosotros no. Al día siguiente llegamos a Guelta, poco antes del anochecer. Encontramos un control de los guerrilleros saharauis en el puesto militar de Janga, que España ya había abandonado. Nos exigieron el permiso que nos tenía que dar la organización en El Aaiún. En ese tiempo, para incorporarte a esa zona del frente, si no tenías permiso de la organización política, no se te permitía pasar. Nos dijeron que no podíamos pasar, que teníamos que volver a El Aaiún para que la ciudad no se vaciara de la población. En esos momentos se había extendido la idea de que el territorio no podía quedar vacío, especialmente de los jóvenes. Les dijimos que ni pensarlo, que no pensábamos pasar ni una sola noche en El Aaiún: los marroquíes ya estaban llegando, queríamos empuñar las armas para luchar y defender nuestra tierra. Finalmente, esa noche no nos dejaron pasar. Entonces decidimos dormir al lado de los guardias. Al amanecer nos dejaron pasar y pasamos.

Cuando entramos en Guelta, vimos que había guerrilleros y también población civil. La situación era muy difícil, demasiado dura. El panorama ofrecía una imagen totalmente misérrima. Aquella realidad, llena de miseria, era chocante: pasamos de la abundancia material, de ir los fines de semana a Las Palmas de Gran Canaria, a la escasez absoluta, empezar a pasar hambre, a experimentar lo que era la limitación de alimentos, los pocos que había. Era pésima la situación. Desalentadora. Pero la preferíamos a quedarnos con el enemigo. Nos sobreponíamos a esa situación gracias una idea, la única idea que nos llevó hasta allí: empuñar las armas y disparar a los echlouha ${ }^{1}$, los invasores de nuestra tierra. Y pensábamos que eso no iba a durar mucho, que los íbamos a repeler rápidamente. Poco después llegaron otros cinco compañeros militantes, que traían al difunto Ebbi, el padre de la traidora Eg' yeimila, que lo habían secuestrado en El Aaiún. Él trabajaba para España, era colaborador, eufemismo que utilizaba España para referirse a los chivatos. Era un chivato. A nosotros nos tocaba empezar la instrucción exprés para prepararnos para el combate. Instrucción o algo muy parecido, el tiempo apremiaba y no había material, recursos ni personal para una instrucción exhaustiva.

\section{La instrucción o algo que se le acerca}

A los cinco que llegaron, nos unimos nosotros. De esos cinco solo queda vivo uno, Mustafa ElAdhli, los demás cayeron mártires en combate. Montamos en los Land-Rover y emprendimos el regreso hacia la zona de Tafudart, a unos cuarenta kilómetros de El Aaiún, en la zona de Doura. En ese momento nosotros no sabíamos hacia dónde íbamos. No teníamos armas, los otros cinco sí. Cuando llegamos, encontramos a un grupo enorme de gente, principalmente combatientes. Encontramos a Mohamed Wadadi y otro grupo. Nos dieron uniformes de combate y armas. ¿Qué armas eran? Viejas, obsoletas,

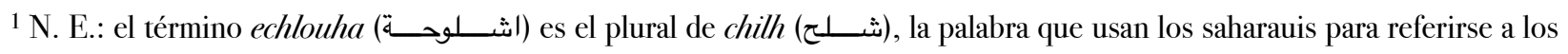
marroquíes. El término deriva de tachelhit (تشلحيت), el dialecto bereber más hablado en Marruecos. 
fusiles de $36 \mathrm{~mm}$, más algunos fusiles igualmente antiguos. Allí mismo nos dieron una lección de cómo se dispara, no había tiempo para más instrucción porque el enemigo se nos echaba encima. No habíamos pegado un tiro en nuestra vida. Yo, de hecho, no sabía nada del manejo de esas armas. Recuerdo que uno de los compañeros casi se vuela un ojo al disparar con el gatillo muy cerca de los ojos. Yo pensaba que el fusil había que ponerlo por encima del hombre, como el lanzacohetes bazooka, en vez de apoyar la culata del fusil en el extremo del pectoral. Entonces pegamos algunos tiros. Conseguimos disparar. Aquello nos encantaba, cada uno llevaba una cadena con munición y el fusil colgando. Como en las películas del oeste que veíamos en el Cine Las Dunas de El Aaiún.

\section{Después de la instrucción, ansias por combatir}

Acabada esa fugaz y rudimentaria instrucción, nos formaron en pequeño pelotón, comandado por el mártir Rgueibi. Éramos casi todos jóvenes de El Aaiún, también había otros hombres mayores, más experimentados que nosotros porque habían estado en el ejército colonial. Nosotros no éramos más que unos chiquillos. Una vez organizados como si fuésemos un ejército regular, con una estructura y jerarquías claras, sin abandonar el método guerrillero, empezaron a organizarse pequeñas patrullas que iban hacia El Aaiún, Tarfaya o Tan-Tan, y siempre volvín con alguna captura. Los coches que teníamos en su mayoría eran donados por particulares, y en algunos casos se trataba de vehículos que habían sido del ejército español y los usaron soldados para desertar y unirse a la guerrilla. Teníamos algo más de armamento, pero eran armas donadas por particulares, otras nos llegaron de la revolución argelina, material viejo pero útil en ese momento. Recuerdo una vieja ametralladora a la que llamábamos "talón de chacal”, se atascaba continuamente, era insufrible manejarla. La organización ya estaba dando resultado.

Cuando empezaron a organizar las patrullas, empezaron a salir y a atacar al enemigo. Pero a nosotros Rguebi no nos dejaba ir porque éramos demasiado jóvenes e inexpertos. Un día decidimos protestar y le dijimos "ipor qué no nos dejas salir a patrullar?, hemos venido para disparar a echlouha". Nos fascinaba la idea de dispararles, estábamos ansiosos. Rguebi, que en paz descanse, nos dijo:

-No os quiero sacar porque no tenéis experiencia militar, no hablamos ya de la experiencia en combate directo en la guerra. Hay entre nosotros gente más mayor y con más experiencia, tenéis que aprender de ellos hasta que tengáis algo más de experiencia para entrar en combate.

Le dijimos que no, que no íbamos a esperar más, que queríamos salir, porque cada vez que salía alguna patrulla volvía con unos echlouha capturados, prisioneros de guerra, y algún civil despistado, “¿qué hacemos nosotros aquí en el cuartel?”. Con su tranquilidad volvió a decirnos:

-La guerra será a largo plazo, os hartaréis de ella vosotros y vuestros hijos -¡lo vio venir, el hombre!-, así que tened paciencia. 
-Vamos a tener paciencia - contestamos-, pero con una condición: cada vez que salga una patrulla, tienen que ir con ella algunos de nosotros.

Aceptó el trato. Cada vez que salía una patrulla, se iban algunos de nosotros. A su vuelta, acribillábamos a preguntas a nuestros compañeros: ¿qué hicisteis?, ¿cómo disparasteis?, ¿cómo es el combate?, etc. Y así comenzamos a introducirnos en el combate directo, poco a poco. Recuerdo que la primera vez que yo fui, los marroquíes iban a invadir a Doura. Nos llegó la información de que iban a entrar esa noche y que salíamos para atacarlos. Nos fuimos hasta una zona con relieves cerca de Doura y nos pusimos en posición esperando a que entraran. Un compañero y yo, los dos muy jóvenes, nos tumbamos por allí con toda la tranquilidad que permitía el desierto. Se nos acercó un hombre mayor, con mucha experiencia en el ejército mauritano pero combatía a nuestro lado, Sidi Ould Sidi Mousa, que posteriormente cayó mártir en combate en Tafudart, y nos dijo: "haced las trincheras, muchachos", pero nosotros no sabíamos cómo. Sidi nos indicó cómo había que hacerlo. Hicimos las trincheras individuales, pusimos piedras alrededor y nos pusimos cuerpo a tierra en posición de tiro. Pero había que esperar. El tiempo de espera se prolongó tanto que yo me quedé dormido, hasta que de repente empezaron a sonar los disparos, ráfagas a un lado y otro; me incorporé y empecé a ver impresionado aquel espectáculo: ascuas rojas a gran velocidad cruzándose conmigo. Los encaré y empecé yo a disparar, ¿a quién disparar o a qué?, a la inmensidad, al vacío, pero eran los primeros tiros que pegaba y había que hacer notar la presencia. Nuestro armamento era inferior, nosotros disparábamos para que ellos supieran que estábamos haciéndoles frente. Ellos venían con su armamento sofisticado, sus tanques y su armamento pesado. Al rato nos ordenaron el repliegue.

\section{Más combates hacia una larga batalla}

Continuamos combatiendo, sin cesar, no sé cuántos meses seguidos, pero aquello no tenía marcha atrás. No paramos de atacar a algunos destacamentos del enemigo. Volvimos a la cinta transbordadora de fosfatos en Bucraa y la quemamos varias veces, había que detener como sea el expolio de nuestros recursos naturales que amenazaba con desangrar nuestra tierra. También atacamos El Aaiún en alguna ocasión. Cuando los estábamos hostigando y vieron que el cerco sobre ellos se estaba estrechando, decidieron atacar nuestro cuartel en Tafudart. Una mañana nos vinieron algunos compañeros de patrullas de avanzadilla para alertaron de que los marroquíes venían desde el norte, con gran despliegue militar. Nosotros empezamos a tener algunas armas modernas, como el mortero ruso PS10 capaz de alcanzar un objetivo a tres y cuatro kilómetros, y también teníamos algunos misiles antiaéreos, pero aún no éramos expertos en su manejo. Ese día empezó la batalla de Tafudart.

Vinieron las tropas marroquíes desde el norte y algunos destacamentos subieron por la zona del río Saguia. La batalla duró todo el día. Conseguimos repelerlos, no pudieron ocupar nuestro cuartel. Cada 
vez que acercaba alguno o varios de ellos, una bala nuestra los atravesaba, y los que venían detrás de salían corriendo para volver a sus posiciones. Y veíamos desde nuestras posiciones cómo sus superiores la emprendían a latigazos contra los que volvían para salvarse. Así estuvimos todo el día, hasta poco antes del anochecer, y ellos no consiguieron entrar. Nosotros tuvimos algunas bajas, cayeron seis o siete compañeros en combate y algunos heridos que tuvimos que evacuar. Del lado marroquí eran incontables las bajas, como si fumigásemos una plaga de langostas. Caían uno detrás el otro.

En ese momento decidimos retirarnos por una cuestión táctica, éramos inferiores en número y equipamiento. Por desgracia, casi todos los coches que teníamos se les dio la orden de llevar a algunas familias, que estuvieron con nosotros a lo largo del día, a Amgala, una localidad situada al este del territorio más segura que Tafudart, pero había que esperar a la noche. En ese momento los coches emprendieron la salida para poner los civiles a salvo en Amgala. Solo nos quedaban dos coches, o a lossumo tres, ahora no lo recuerdo muy bien, el que tenía el mártir Rgueibi, recuerdo que ese día el compañero Mohamed Wadadi fue herido y lo evacuaron en otro coche con los heridos. Quedaron, pues, dos coches, uno para llevar nuestros víveres, principalmente dátiles y leche, además de las provisiones de combustible, y otro que llevaba artillería y munición. Subimos hacia una zona estratégica, río Saguia arriba, teníamos que ir a preparar la comida a la gente. Teníamos que organizarnos de tal forma que había conseguir la evacuación de toda la gente: lo hacíamos por grupos, divididos en diferentes puntos, para ir alcanzando los unos a los otros. Finalmente echlouha entraron en Tafudart, pero no encontraron a nadie. A nadie vivo.

Una vez establecido en Tuaghet, un punto estratégico en el río Saguia, pernoctamos allí una noche, y a la siguiente noche nos enviaron los refuerzos desde Amgala para socorrernos, cuando los coches se quedaron libres, y nos evacuaron hacia esa parte libre de presencia de marroquíes. A los coches que habían partido de Tafudart, se les unieron otros más, al mando de los cuales iba el difunto Mohamed Rahal (que llegó a ser presidente del parlamente saharaui). Llegaron en el momento indicado, porque desde Smara venía un gran batallón marroquí, que si no llegamos a salir a tiempo, nos habría sitiado e interceptado en el camino y aquello hubiese sido una carnicería. Además, venían otros batallones desde El Aaiún, apoyados por helicópteros y aviones de combate. Nosotros éramos 300 o 400 combatientes, un número infinitamente inferior frente a los batallones que nos estaban pisando los talones con toda esa exhibición de poderío y armamento sofisticado.

\section{Reorganización desde la retaguardia}

Una vez a salvo en Amgala, y después de dos días de descanso, vinieron tres altos dirigentes del Frente Polisario. Eran Luali Mustafa Sayed, que era el Secretario General del Frente Polisario caído en combate en junio de 1976 en un ataque a la capital mauritana, Brahim Gali, durante muchos años 
Ministro de Defensa saharaui y actualmente responsable de Organización Política del Frente Polisario, y Ayub Lehbib, que fue jefe de la $3^{\text {a }}$ Región Militar del Frente Polisario durante muchos años y actualmente está en el bando marroquí, después de una sonada traición en 2003. Nos pusimos en formación para escuchar la arenga del Secretario General del Polisario, Luali Mustafa, y evaluar la batalla. En la arenga había reproches intencionados, más para levantar el ánimo que para recriminarnos nuestra decisión de retirada de Tafudart. Dijo cosas como “¿por qué habéis salido huyendo de allí?, ¿por qué no continuasteis la batalla?, teníais que haber hecho frente al avance marroquí”, etc., pero él era consciente de nuestra inferioridad numérica, los reproches eran más una forma de levantar el ánimo de los civiles, para que viesen que había dirección, que había preocupación y que estábamos combatiendo. A Luali lo acompañaban algunos militares argelinos, pero ahora mismo no recuerdo ni su rango ni mucho menos los nombres. Era diciembre de 1975, siete meses después Luali cayó en combate, alcanzado por un misil francés, en las inmediaciones de Noukchout, capital de Mauritania, a donde fue al mando de un grupo de combatientes para llevar la guerra al interior de uno de los países invasores.

Cuando hubo terminado su arenga, Luali se acercó a Rgueibi, nuestro comandante, para decirle que los chicos más jóvenes, en referencia a nosotros, tenían que ir a estudiar, a formarse. Rgueibi le contestó que no, que esos jóvenes eran muy buenos combatientes, mejor incluso que los mayores, y que no se iba a separar de ellos. Entonces Luali le ordenó que cogiera a sus mejores hombres, los equipara con armamento y coches, y a la par tenía que formar un batallón para que se fuera a recibir más instrucción. Rgueibi seleccionó a ciento veintiocho hombres, si mal no recuerdo, para que nos quedáramos con él, el resto se fue a hacer la instrucción militar especializada.

Quienes tuvimos que quedaron nos aprovisionaron de armas, ya contábamos con el fusil automático de fabricación soviética AK-47 Kalashnikov, coches y otro tipo de material necesario para las batallas, aparte de los víveres y demás productos básicos. Ahora tenemos mejor equipamientos que antes, pero nuestros recursos siguen siendo limitados. Seguimos en inferioridad. Emprendimos la marcha de Amgala rumbo a Rgheiua, otro punto estratégico cerca de Meheris, también en la parte este del territorio. Rgheiua, además, es un lugar simbólico: en 1958 el Ejército de Liberación humilló en esa zona a las tropas francesas, que se habían infiltrado en el territorio desde Mauritania, ansiosas por aniquilar los focos de resistencia anticolonial en todo la región. En Rgheiua establecimos nuestro cuartel de operaciones, pero al cabo de unos días nos ordenaron a algunos ir a acompañar a algunas familias que estaban en Umat El-Lham, cerca de Bir-Lehlu, que las teníamos que escoltar hasta llevarlas a una zona segura. Por suerte vinieron camiones de la Media Luna Roja Argelina, que traían ayuda humanitaria, para llevar a las familias, y nuestra misión fue la de asegurarles el camino para evitar sorpresas. Lo que quedó del batallón se fue a Tifariti. Cuando conseguimos llevar a las familias, alcanzamos a los demás en Tifariti. 
Por esas fechas el Secretario General de la ONU, el austríaco Kurt Waldheim, iba a visitar la zona. Argelia ordenó la retirada de todos sus efectivos en la zona: ¡qué de comida, ropa y alimentos dejaron! ¡Qué festín! Nos equipamos muy bien, con camiones, alimentos, ropa y munición. De allí nos fuimos a Lemgasim, otro punto estratégico, y allí se nos unió Mohamed-Lamin Buhali, quien sería después Ministro de Defensa, con un batallón recién graduado después de un periodo de instrucción, y entre ese batallón y el nuestro, el del mártir Rgueibi, creamos la 2a Región Militar del Ejército de Liberación Popular Saharaui. Antes se había formado la 1a Región Militar, comandada por Mohamed Abdelaziz, quien sería presidente de la República Saharaui hasta su fallecimiento el pasado 31 de mayo de 2016 . Y de allí empezó la organización de todas las demás regiones militares, hasta siete en la actualidad.

A partir de entonces, con el ejército organizado en sus diferentes regiones, cada cual con sus batallones y legiones, de nuevo empezamos a atacar al enemigo. Había que participar en todas las batallas, ¿qué hacía uno sentado sin luchar?, los permisos eran escasos. A veces me concedían permiso de un mes para ir con mi familia, pero se interrumpía a los quince días porque había una llamada a filas otra vez o porque se decretaba el toque de queda por alguna emergencia en el frente de batalla. Participé en todas las batallas antes de ser capturado, con breves lapsos de tiempo después de las heridas sufridas en algunas batallas, que me obligaron a estar en reposo durante un largo periodo de tiempo.

\section{Las huellas de la guerra en el cuerpo}

La primera vez que me hirieron en el campo de batalla fue en el año 1977. Una bala me alcanzó en la mano izquierda. $\mathrm{Al}$ año siguiente me alcanzaron en el pie, pero de la forma más inesperada. Hubo una mezcla de torpeza y valentía, no sé, o un simple descuido imperdonable que casi me cuesta la vida. Entramos en combate cerca de Haguniya, en una llanura extensísima, con una patrulla de echlouha. Empezamos el intercambio de disparos, yo conducía un coche con una ametralladora, en un momento de la escaramuza capturamos a dos soldados enemigos, que resultaron ser saharauis alistados en las Fuerzas Armadas Reales de Marruecos. Los subimos a los dos en el coche que conducía yo. Continuamos el combate y en un momento dado detuve el coche porque tenía un buen ángulo de visión, tenía a varios de ellos a tiro, y justo en ese momento un disparo alcanzó el coche. Se apagó el motor y no lo pude arrancar. ¡No hay que detener nunca el coche en combate!, tiene que estar moviéndose continuamente para evitar que lo alcanzaran los disparos. Le dije a un compañero “creo que el coche fue alcanzado”. Me apeé del coche y abrí el capó con toda tranquilidad para ver qué le pasaba. Nada más abrir el capó un disparo certero me alcanzó en el pie izquierdo. Con el pie sangrando, yo seguía gritándole a mis compañeros que el coche había sido alcanzado. En ese momento uno de los prisioneros saltó del coche y huyó para ponerse a salvo. Avisé a otro compañero de que el prisionero había huido, le dio un tiro y se cayó herido. Años después lo encontraríamos en prisión cuando vino a visitarnos porque un primo suyo era uno de 
mis compañeros. En el otro coche que teníamos detrás, el conductor vio el humo salir del nuestro, se acercó, nos rescató rápidamente y nos marchamos.

La tercera herida fue en la batalla de Aljelua, al sur de Marruecos, en la que capturamos a un capitán del ejército marroquí y a muchos soldados y oficiales. Era el año 1979, en el mes de mayo o junio, no lo recuerdo bien, pero me acuerdo de que hacía un calor sofocante. Era la primera vez que se efectuaban operaciones conjuntas de todas las regiones militares. Por entonces habíamos decidido ejecutar una táctica arriesgada pero efectiva: cuando veíamos los echlouha, varios coches aceleraban hacia ellos, como si los fuésemos a embestir, para provocar su dispersión, desconcertarlos y diezmar sus unidades. Se desconcertaban tanto que emprendían la huida sin orden ni concierto. Eso funcionaba, nuestra inferioridad numérica había que contrarrestarla con maniobras agresivas como ésta. Si te limitas a un enfrentamiento clásico, te liquidan con su artillería pesada. Entonces ese día se decidió ejecutar esa táctica habitual. Yo era el conductor y conmigo venían Suelki, jefe del batallón, y Omar el Canario, fotógrafo. Habíamos acordado que nada más ver a los echlouha íbamos a precipitarnos sobre ellos varios coches. Cuando los tuve al alcance, aceleré el coche hacia ellos, pero nadie me siguió. Ya habíamos penetrado dentro del batallón marroquí y estábamos solos. Algunos de los soldados marroquíes estaban en posición de tiro en el suelo, agazapados, y uno de ellos me disparó. Su bala me atravesó la barbilla por el lado derecho y salió por el maxilar inferior izquierdo. Me lo dejó hecho añicos. De repente tenía las muelas desperdigadas por la boca, no podía hablar, ni siquiera abrir la boca y tuve que reaccionar rápido. Avisé al jefe del batallón, dándole un leve codazo, de que me habían herido y le señalé la barbilla; él me preguntó si quería que nos intercambiáramos, pero le dije que no; conseguí dar la vuelta rápidamente y retirarme hasta alcanzar a los demás compañeros.

La rápida intervención del enfermero del batallón, que me puso los primeros puntos de sutura, consiguió salvarme. Esa misma tarde decidieron llevarme a Rabuni, cerca de Tindouf. A mitad de camino, hicimos una parada en el cuartel, para que me hicieran algunas curas, y al día siguiente continuamos hasta Rabuna. El viaje se me hizo eterno, porque a lo largo del camino me moría de sed, pero no podía beber. Los que me acompañaban intentaban suministrarme agua, pero tenía hinchada la garganta. Cuando llegamos a Rabuni me llevaron a Tindouf y al día siguiente me evacuaron en avión a Argel. Me llevaron al hospital de Aein Naâdja y empezaron a reconstruirme el maxilar. Estuve siete meses con las mandíbulas inmovilizadas, con unos hierros bloqueantes; todo lo que ingería estaba triturado, no podía masticar. Terminados los siete meses, me dieron de alta. Volví a los campamentos.

A principios de 1980 se decidió enviar a un grupo de heridos a Yugoslavia para ser tratados. Era el primer grupo, más de veinte personas, que viajaba a esa zona y yo fui con ellos como responsable del grupo. Se trata de heridos que ya no tenían posibilidad de arreglo en Argelia, porque requerían de operaciones demasiado complejas o requerían recursos que no estaban disponibles en Argelia, por eso se 
decidió enviarnos a Yugoslavia. Enviaron con nosotros al diplomático saharaui Ould Ebseiyit, con el pretexto de que estaba enfermo, para que hiciera los primeros contactos para buscar apoyos a la causa. Antes de llegar a Yugoslavia nos dijeron que debíamos tener un comportamiento ejemplar, porque de eso dependía el éxito del diplomático infiltrado entre nosotros. Nada de hacer té, jcon lo que nos gusta a los saharauis la ceremonia del té!, durante la estancia. En Belgrado nos recibieron y nos preguntaron por las lenguas que hablábamos. Nos dieron traductores y nos distribuyeron en varios hospitales. Económicamente lo pasamos bastante mal, había fumadores que no tenían ni para tabaco, y aún a día de hoy temo que nos hayan dado alguna asignación para ese periodo y haya acabado en los bolsillos del diplomático. Eso es lo de menos. El caso es que empezaron a tratarnos a todos. Yo procuré hacer visitas periódicamente a los demás compañeros en los diferentes hospitales, por si a alguien le hiciera falta algo. En mi caso, para tratarme la boca, un médico me propuso dos alternativas: recomponerme el maxilar con una de mis costillas y se quedaría el maxilar como nuevo, pero eso tenía el riesgo al rechazo; la otra era colocarme unos implantes sobre la prótesis que llevaba. Opté por la segunda, era la más sencilla y rápida. $\mathrm{Al}$ cabo de seis o siete meses volví a los campamentos. Estuve en los campamentos hasta que nació mi hijo Seif, en agosto de 1980. Mientras estuve en los campamentos, solo tenía entre ceja y ceja volver de nuevo al campo de batalla.

\section{La vuelta al combate: Marruecos se refugia en sus muros}

Descansé y después me fui de nuevo a las regiones militares. A mi región militar, que era la segunda. Ese era el deseo de todos los combatientes: estar el menos tiempo posible en la retaguardia y el máximo posible en el campo de batalla; éramos los albañiles de la libertad de nuestro pueblo, la estábamos construyendo. A mi vuelta, en los dos primeros años, participé en multitud de batallas, que me es difícil relatar en este momento por cuestión de espacio. La contienda era asimétrica en recursos y en número de soldados; también en convicción: nosotros luchábamos por convicción, ninguno de nosotros tuvo nunca un sueldo, jamás, porque la única recompensa que buscábamos era la liberación de nuestra tierra. Marruecos invertía la mayor parte de sus ingresos en el pago y equipamiento de su soldadesca. Aun así conseguimos derribar aviones, capturar altos cargos, infligir sonadas derrotas a uno de los

ejércitos mejor equipado de la región. Cada vez que le asestábamos un golpe al enemigo, su economía se desangraba. Cada vez que intentaban avanzar, les repelíamos con arrojo a pesar de su superioridad numérica. Cada vez que intentaban extender sus intervenciones, allá donde vayan hay algún batallón saharaui a la espera. Nosotros conseguimos avanzar en la liberación de nuestra tierra, es entonces cuando Marruecos decidió introducir un nuevo elemento en la guerra: los muros. Estaba claro que había fracasado en sus intentos de ocupar todo el territorio, por eso inició la construcción de los muros. La 
intención era impedir nuestro avance y proteger los recursos naturales que había empezado a explotar nada más ocupar el territorio.

Con el levantamiento del muro, se produjo un gran debate en nuestras filas. Los superiores nos dieron una indicación clara: hay que impedir la construcción del muro, porque de levantarse estaríamos arrinconados en Argelia. Pero las tropas del enemigo eran demasiadas, aumentaban cada día y se centraron en la defensa del muro para que fuera construido. Los nuevos cálculos obligaron a nuestros mandos a cambiar de estrategia y decidieron dejar que los marroquíes construyeran su muro y resolvieron que había que volver a las acciones de guerra de guerrillas. Por esa época, ya en 1982, yo fui ascendido a jefe de sección y me tocó participar en el 5 Congreso Popular General del Frente Polisario, celebrado en los Campamentos de Refugiados en octubre de ese año. En el Congreso se decidiría la nueva estrategia de enfrentamientos en las líneas del frente. Una de las resoluciones del congreso fue la creación de unidades de reconocimiento y vigilancia del enemigo en cada una de las regiones militares. Me tocó formar parte de la Unidad de Reconocimiento de la 2a Región Militar del Ejército de Liberación Popular Saharaui. Yo era el adjunto del jefe de la unidad, Habib Mahayoub, quien sería mi compañero de cautiverio durante 12 años en las prisiones de Hassan II.

Empezamos nuestra labor de reconocimiento y vigilancia, teníamos que vigilar al enemigo, sus posiciones, sus movimientos y su material, si tienen o no material nuevo, con qué frecuencia reciben suministro, etc. Además de eso, llevábamos a los cuadros del ejército para enseñarles las posiciones y bases del enemigo, especialmente para estudiar y preparar las operaciones e intervenciones nuestras. Planificar bien las intervenciones, en qué punto exactamente se piensa intervenir, si se trata o no de un punto estratégico. Continuamos con nuestro trabajo, el de reconocimiento y vigilancia, hasta que fuimos capturados el 8 de mayo de 1984 a las 17:00h y a lo largo de ese día la tormenta de arena, con todo su rigor, había dejado invisible el terreno.

\section{Captura en la batalla}

Antes de que nos capturaran estábamos en los campamentos, donde pasamos aproximadamente una semana por una alerta. Nos informaron de que los marroquíes iban a construir otro muro, un tramo nuevo que viene de Echederíya. Antes de volver de nuevo a la Región Militar, quería ir a la Dirección de Suministros del Ministerio de Defensa, de la que era responsable Babiya Chiâa, para recoger un pedido pendiente, un material que necesitaba para nuestro trabajo, como prismáticos y otros elementos de vigilancia. Babíya me dijo que aún no había llegado, que me esperara unos días más. ¡Si hubiese esperado para recoger el material, no me habrían capturado! Le dije que no podía esperar más tiempo, que había una emergencia y las patrullas de reconocimiento tenían que volver al trabajo de forma inmediata. Le encargué que me enviara el material cuando lo tuviera, o en caso de que yo volviera otra vez a los 
campamentos, lo recogería. Teníamos prisa por incorporarnos, no podíamos esperar más, así que nos preparamos con el equipamiento que teníamos, los víveres necesarios, la munición y nos fuimos hacia la zona de Houza.

En Houza encontramos a todas las regiones militares posicionadas en la zona. Al mando estaba el presidente Mohamed Abdelaziz, que en la batalla solía ser el primero y era tan contumaz que se negaba a retirarse, especialmente cuando la batalla se tornaba cruenta por el armamento pesado del enemigo. En esa batalla fueron capturados algunos compañeros de la segunda región militar, otros cayeron mártires. Fue una batalla difícil. Finalmente se ordenó el repliegue y replegamos.

Al día siguiente en mi Unidad de Reconocimiento decidimos salir a patrullar. Queríamos saber el avance del enemigo y a qué altura habían llegado. Los demás compañeros nos desaconsejaron salir, por el mal tiempo y porque ese día traían a un camello entero para sacrificarlo y hacer un festín para los combatientes. Pero no atendimos a sus súplicas. Había que seguir el avance del enemigo y esa era nuestra responsabilidad como Unidad de Reconocimiento. La tormenta de arena, el siroco, hacía impracticable nuestra labor, pero a pesar de ello salimos a patrullar dos coches, con cuatro combatientes cada una. Nos dirigimos a Houza de nuevo y en el camino encontramos a un batallón de la $3^{\text {a }}$ Región Militar y les preguntamos por el avance de echlouha, pero no sabían nada. La tormenta de arena alcanzaba su máxima intensidad y la visibilidad era prácticamente nula. Uno de los compañeros, que conocía bien la zona, dijo que eran muy frecuentes las tormentas de arena. Seguimos nuestro camino hasta llegar a Lefreirinat, una zona al sur de Houza, y al subir a un montículo los marroquíes nos sorprendieron de cerca. Estaban a un palmo, muy cerca. Intentamos el regreso, pero ya era demasiado tarde. Empezaron a dispararnos. Dejaron inutilizadas las cuatro ruedas de nuestro coche. El otro coche consiguió escapar, pero fue alcanzado por un cohete; por suerte un tercer coche, de un batallón de la $3^{\text {a }}$ Región Militar, rescató vivos a los compañeros y los llevaron a los cuarteles. Eran muchísimos los marroquíes y empezaron a dispararnos indiscriminadamente y utilizando todo tipo de armamento: fusiles de asalto, lanzacohetes, lanzagranadas; ¡no ahorraron en gastos! Nosotros también empezamos a disparar: como el coche ya no ofrecía resistencia, saltamos de él, nos dividimos de dos en dos y la emprendimos a tiros contra ellos. Éramos cuatro contra un batallón. Nos llovían disparos por todas partes, nuestros uniformes estaban agujereados y seguíamos de pie resistiendo las embestidas del enemigo hasta quemar las últimas balas de las recámaras de nuestros Kalashnikov. Ningún disparo nos atravesó el cuerpo, aunque fuese ese nuestro deseo en ese momento para no caer en las manos de echlouha; por eso saltamos del coche, para que nos dieran sepultura antes de capturarnos vivos. Nuestra reserva de munición se quedó en el coche y con los fusiles secos nada podíamos hacer. Ellos siguieron disparando. A mí me alcanzaron en la pierna, y al compañero que tenía al lado, lo alcanzaron en la cadera. A los otros dos también los hirieron, pero no en 
órganos vitales. No era creíble, pero sucedió así. Es como si Allah hubiese puesto un manto de acero invisible entre nuestros órganos vitales y las balas marroquíes.

Los cuatro detenidos éramos Habib Mahyoub, jefe de la unidad; yo, Sid Ahmed Hnini, adjunto del jefe; Bouzeid Mohamed-Lamin, enfermero; y Mrabih Eddoua, conductor. "Rendíos", nos dijeron. Nos negamos. Queríamos que nos pegaran cuatro tiros certeros, pero no lo hicieron. Nuestros fusiles sin una sola bala, esa ya era suficiente señal para que entendieran que no teníamos con qué continuar. Entonces una jauría de echlouha se abalanzó sobre nosotros y nos hicieron en recibimiento caluroso. Muy caluroso: patadas, bofetones, insultos, vejaciones. Daba igual dónde caía la patada o el bofetón, el caso es pegarnos y descargar en nosotros toda la ira que llevan acumulada por su fracaso en el combate. ¡No esperábamos menos! Unos vienen a vengar la muerte de un hermano. Otros nos acusan de dejarlos huérfanos. Algunos más amenazan con hacernos de todo, soltando por la boca toda la verborrea soez que un ser humano puede decir, lo más bajo y abyecto en la moral musulmana salía por la boca de esos soldados desnutridos. Todos eran soldados rasos, furiosos y descontrolados, alimentados por las ansias de aniquilar a un pueblo entero. Nos registraron deseando encontrar algún tesoro, algo de valor que diera significado a la captura, pero no encontraron nada; los soldados marroquíes, con todo el dinero que inyecta en ellos su monarca, estaban hambrientos y desesperados. Tiempo después un compañero, que fue capturado antes que nosotros, nos contó que lo registraron y solo encontraron un palo corto y fino que sirve para limpiar los dientes, llamado miswak, en uno de sus bolsillos: recibió la paliza de su vida por no llevar nada de valor que pudieran confiscarle. La lluvia de patadas y bofetones no cesó hasta que llegaron los oficiales, que nos querían vivos en sus manos. Era tal el estado de aturdimiento y nerviosismo en que estábamos, que uno de ellos me puso un cigarrillo de Marlboro en la boca y me lo fumé de sopetón después de cinco años de haberlo dejado.

\section{En manos del enemigo}

Los oficiales nos subieron a una ambulancia para trasladarnos a otro lugar. La jauría de soldados seguía con su festival de rugidos de fieras hambrientas, crecidas ante un adversario herido, sin armamento y en inferioridad numérica. En su escalada de protestas, la emprendieron a golpes contra la ambulancia en la que nos metieron, ya de noche, para curarnos. De eso se encargó un joven teniente, secretario del coronel que se encargaba de interrogarnos. El teniente nos aseguró que mientras estuviéramos bajo su responsabilidad y custodia, no teníamos que temer a nadie. Fue amable en todo momento y consiguió que nos curaran en atención primaria. No olvidaré jamás a aquel joven teniente, un hombre al que la guerra tenía traumatizado e infeliz, según me contó, porque era incapaz de conseguir hacer una vida normal sin que acudan los recuerdos de la guerra para perturbar su tranquilidad: me confesó que cuando va a Casablanca, Rabat o cualquier otra ciudad marroquí, puede estar en la cama con 
alguna amante y estar en todo momento ausente, con la mente centrada en la guerra del Sáhara. También recuerdo un consejo suyo, el consejo del enemigo, cuando me dijo que una vez acabada esa pesadilla, tenía que ponerme a escribir mi experiencia, todo lo que había pasado y vivido. En parte estoy dando curso a esa petición del enemigo. Él y su jefe nos trataron con respeto, a veces el jefe en los interrogatorios llegó a soltar algún insulto, pero jamás nos tocó. Esa era la gran diferencia entre los oficiales y los soldados. No sé ahora si nos trataron con tanta deferencia por propia voluntad u obedeciendo a órdenes de sus superiores.

Pasamos allí la noche y al día siguiente nos llevaron a un lugar en el que un helicóptero nos recogió para llevarnos a Smara y luego a El Aaiún. Cuando subimos al helicóptero, el oficial le dio instrucciones al piloto para que nos tratara bien. Al llegar a Smara para repostar combustible, apareció un negro gigantón cuya presencia era temible para sus propios compañeros, todos ellos gendarmes, que nada más verlo acercarse uno de ellos soltó “ilo que les viene encima, pobrecitos!”. Apareció el negro gigantón y vio que estábamos esposados, pero no era suficiente para él: echó mano de una cuerda gruesa, de unos veinte milímetros de grosor, de tacto áspero, creo que de paja o de pita, y empezó a maniatarnos las manos en un barra superior, con tanto fuerza que nos congeló la circulación y las rozaduras nos provocaron unas heridas en las muñecas. Y reanudamos en vuelo hacia El Aaiún. Aquella fue la escena más triste, dura y humillante, volver a la ciudad en la que naciste y creciste esposado y maniatado, ver la ciudad de la que saliste hace apenas unos años desde el cielo y encontrarla tomada, controlada y ocupada por una potencia invasora, ¡qué rabia e impotencia provocaba aquella imagen! Aterrizamos en el aeropuerto militar por la tarde.

\section{Primeros interrogatorios y salida deEl Aaiún}

En el aeropuerto empezó el primer interrogatorio. Parece ser que por esos días habían extendido el rumor de que Brahim Gali, el ministro de defensa de la República Saharaui y el terror del ejército marroquí, había sido abatido en la guerra. No sabíamos si se trataba de una maniobra para minar nuestro ánimo, levantar el de sus tropas, o simplemente algún traidor retornado les había dado una información falsa para contentarlos, porque Brahim Gali aún sigue vivo mientras se escriben estas líneas. "Brahim Gali ha muerto", fue lo primero que nos dijo un oficial, "nosotros lo dejamos vivo", respondimos. "No añadió-, murió en la batalla de Guelta”, afirmación a la que siguió un reguero de insultos por no haberles confirmado la noticia. "Si vosotros lo queréis matar -replicamos-, matadlo, pero nosotros lo dejamos vivo".

En ese momento llegó el turno de los pilotos de ataques aéreos. “¿Cuál es el alcance de los daños que os causan nuestros bombardeos?”, fue la pregunta más repetida. “A veces causan algún daño, otras veces, Alhamdulillah, no causan nada, que es la mayoría de las veces", respondimos. Aquella respuesta 
no era la esperada, causaba estupor e indignación en ellos, porque había que reconocerles, desde su posición de pilotos, la eficacia de sus aviadores y el alcance destructor de sus bombardeos. Minimizar su impacto no encajaba, ni de lejos, con su visión sobre el terreno de combate que nunca pisaron. Menos aún esperaban nuestra respuesta, tan directa y decidida. Les dijimos que nuestras unidades actuaban con gran movilidad, que estábamos en enfrentamientos directos con ellos y que apenas era significativo el alcance de los ataques de su aviación. Pero ellos necesitaban otra respuesta para levantar su ánimo y el de sus aviadores de combate. Les dijimos "no, no os vamos a mentir y os contamos la realidad tal cual sobre el escenario del combate”. El interrogatorio continuó toda la noche, sin comida, sin bebida y sin descanso. La comida ni nos entraría en ese momento, pero al manos algo de agua nos hubiera venido bien para hidratarnos. Nos lo negaron todo, haciendo efectivo el dicho de "al enemigo, ni agua". Ellos buscaban una verdad que nosotros no podíamos darles, una verdad alejada de la realidad del terreno en el que caímos capturados luchando y que muchos de ellos no habían pisado jamás.

Al día siguiente, 10 de mayo de 1984, mientras se festejaba en los campamentos de refugiados y en las zonas liberadas el XI Aniversario del Frente Polisario, nos trajeron ropa civil, indumentaria tradicional marroquí, iprimer intento de asimilación!, algo que entendimos más tarde cuando nos subieron a un avión comercial con destino a la ciudad marroquí de Agadir. Nos pusieron esos ridículos harapos, nos esposaron las manos por dentro de las chilabas y nos subieron a un Land-Rover con los ojos vendados para llevarnos hacia el avión. Una vez en el avión, vimos que había entre los pasajeros algunos saharauis, pero sobre todo había marroquíes. Entonces algunos empezaron a murmurar "prisioneros, prisioneros...”. Cuando el avión despegó, vino la azafata para servir el tentempié habitual en los aviones, agua, zumos o refrescos, e intentó servirnos pero el guardián que venía con nosotros, un gendarme, le dijo que no, que a nosotros no nos sirviera nada. “'Será cabrón!”, fue lo que pensé en ese momento. Continuamos el viaje hasta Agadir, allí nos bajaron y nos llevaron a otro centro de interrogatorios.

\section{En el centro de detención de Agadir}

Nada más bajar del avión en Agadir, poco antes de la puesta de sol, nos esperaban unos Jeeps del ejército marroquí, nos vendaron los ojos, nos subieron a los coches y nos llevaron hacia el centro de interrogatorios donde estaban otros compañeros que fueron capturados antes que nosotros. Había un grupo de prisioneros capturados en una batalla cerca de Amgala en el noreste del Sahara, y otro grupo detenido un día o dos después de nosotros, pero que no había pasado por El Aaiún sino que fue trasladado directamente a Agadir. Nos metieron en unos almacenes subterráneos en los que se guardaban los uniformes y la indumentaria del ejército, que desprendía un fuerte e insoportable olor a productos químicos. En ese espacio forzaron la construcción de pequeñas celdas, mazmorras, con letrinas y luz y allí nos metieron a nosotros. Vimos que allí había otros grupos, pero la comunicación 
estaba prohibida en todo momento. Nosotros cuatro estuvimos juntos, los demás estaban aislados de uno en uno. Y se reanudaron los interrogatorios.

Cada interrogatorio empezaban por la mañana hasta altas horas de la madrugada, sin parar. No había límite de tiempo. Preguntaban toda suerte de estupideces, cosas sin sentido, y ellos lo sabían, porque toda aquella información que buscaban les había llegado de los traidores retornados, y además nos lo decían los oficiales marroquíes: "tenemos toda la información por la que os vamos a interrogar, pero es una orden que tenemos que cumplir, preguntaros por algo que ya sabemos a través de los retornados". Una de esas estúpidas preguntas era sobre la división administrativa en los campamentos de refugiados, cuántas dairas (distritos) y wilayas (provincias), en lo civil, y cuántas regiones militares había, en el terreno bélico. Preguntas sin sentido en ese momento, ya lo sabían ellos, pero preguntaban de todas formas. Si tenían a los retornados, los traidores, para qué preguntaban. De hecho allí nos encontramos con varios de ellos, recuerdo que vimos al traidor Mohamed Moulud Tami, que formaba parte de la $2^{\text {a }}$ Región Militar del Ejército Saharaui y era comisionario político, también encontramos al

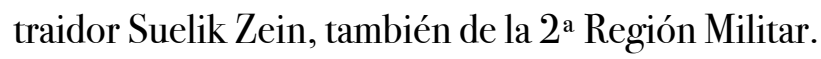

En esos interrogatorios, algunos de los compañeros, que se sentían demasiado intimidados, asustados y vencidos por el miedo, contaron lo que sabían y lo que no lo sabían se lo inventaban. Lógico que con tanta amenaza se debilitaran. La tónica general era más bien de enfrentamiento en los interrogatorios: nos enfrentábamos a ellos con la verdad del terreno. Me acuerdo de una noche en la que vino a interrogarme un coronel, en pleno mes de Ramadán, me preguntó por algunas batallas concretas en las que yo había participado: “¿cuáles fueron vuestras pérdidas?”. Le di un balance detallado de lo que nosotros perdimos y lo que ellos perdieron: algunas bajas nuestras, muy pocas, aparte de algunos heridos, frente a las grandes pérdidas que les causamos, con bajas mortales, prisioneros, derribo de aviones de combate, inutilización de tanques y otros materiales y recursos bélicos de los que ellos disponían, además de confiscación de munición, fusiles, vehículos (coches y camiones), tanques, armamento pesado, e incluso suministros. En esas batallas por las que me preguntó ese había sido el resultado. "Mientes”, me soltó, “¿qué pasa, que nosotros os disparamos con dátiles y flores y vosotros nos disparáis con fuego y munición reales?”. Le contesté: “así fue, yo te cuento la verdad, lo que ocurrió, en la batalla perdemos poco, vosotros lleváis la peor parte”. Nos enfrentamos dialécticamente en ese momento, para que al final él se decantara por un argumento que le parecía más convincente: "mira -me dijo-, a vosotros os drogan, entráis en la batalla drogas, porque no puede ser que nosotros con nuestra superioridad numérica y en recursos, no os superemos en esas batallas. Os drogan, Argelia os droga. Porque os disparamos con artillería pesada, misiles de corto y largo alcance, aviones de combate, y no retrocedéis ni replegáis en la batalla, ¿cómo se explica vuestra actitud?”. Le contesté: “¿no ves que la diferencia está en que nosotros luchamos por convicción? No somos asalariados, somos un ejército de 
voluntarios. Nuestra causa es justa y sabemos que llevamos razón”. Volvió a insistir en el asunto de las drogas:

-No, no, -insistió el coronel-, os drogan.

-Las drogas no existen en nuestra tierra-le contesté.

-Os la ponen en la comida - volvió a insistir.

-La comida nos la hacemos nosotros.

-Entonces os la ponen en el agua -dijo agarrándose desesperadamente al argumento de nuestra supuesta drogodependencia.

-El agua la sacamos nosotros de los pozos.

Y así continuamos la batalla dialéctica un buen rato, él insistiendo en encontrar una explicación que le parezca más lógica al arrojo temerario de los combatientes saharauis en la batalla, y nosotros sin abandonar el argumento que nos llevó a empuñar las armas para morir por nuestra tierra y morir en nuestra tierra, porque ese es el argumento de la convicción de una lucha justa que, aunque estuviésemos en manos del enemigo, no íbamos a traicionar jamás.

El grado de serenidad que mostramos empezó a hacer su efecto entre las propias filas del enemigo. Hasta nos llegaron a reconocer nuestra capacidad de resistencia y lucha. Recuerdo que un día nos llevaron maniatados delante de otro grupo de oficiales, para otro interrogatorio. Entre los oficiales había un coronel que al vernos entrar le dijo a un oficial: "yo tengo más confianza en estos maniatados que hemos capturado empuñando sus armas para matarnos, que en esos traidores retornados, porque como traicionaron a los suyos, cualquier día pueden traicionarnos a nosotros. A estos, sin embargo, se les pega, fueron capturados luchando por su tierra". Ese fue el reconocimiento de un coronel del ejército enemigo. En otra ocasión, en un ambiente algo más distendido, estuvimos hablando con los oficiales marroquíes, uno de ellos dijo: "Hassan II os maldice día y noche, porque si no llegáis a interponeros en nuestro camino, hoy seríamos los dueños absolutos de todo el Magreb Árabe, pero vosotros nos lo impedisteis". Este reconocimiento es incluso mejor que el anterior, porque deja claro que el proyecto de la gran expansión del reino marroquí fracasó gracias a nosotros. Y así es, ese proyecto existía desde finales de los años cincuenta y nosotros conseguimos abortarlo cuando empezó a gestarse sobre el terreno. Ese mismo oficial añadió: "Boumedienne [ex presidente argelino] nos engañó, nosotros nos quedamos con la tierra, pero él se llevó a los hombres”. Si no llega a ser por los saharauis, hoy Mauritania estaría sufriendo la misma ocupación y represión que padecen cada día los saharauis en los territorios ocupados del Sahara Occidental.

Finalmente, cuando vieron que se agotaba toda suerte de artimañas para desviarnos de nuestra lucha (¡llegó un momento en el que casi nos ofrecían hasta el trono del rey!), se les ocurrió permitir las 
visitas en prisión, cuatro meses después de habernos detenido. Las visitas eran en realidad una forma de intentar convencernos de lo bien que se está bajo la ocupación, de que era mejor pasarse al otro lado. Aquí tengo que aclarar que las visitas son de los familiares que estaban en las zonas ocupadas, porque los que están en los campamentos no sabían si estábamos vivos o muertos.

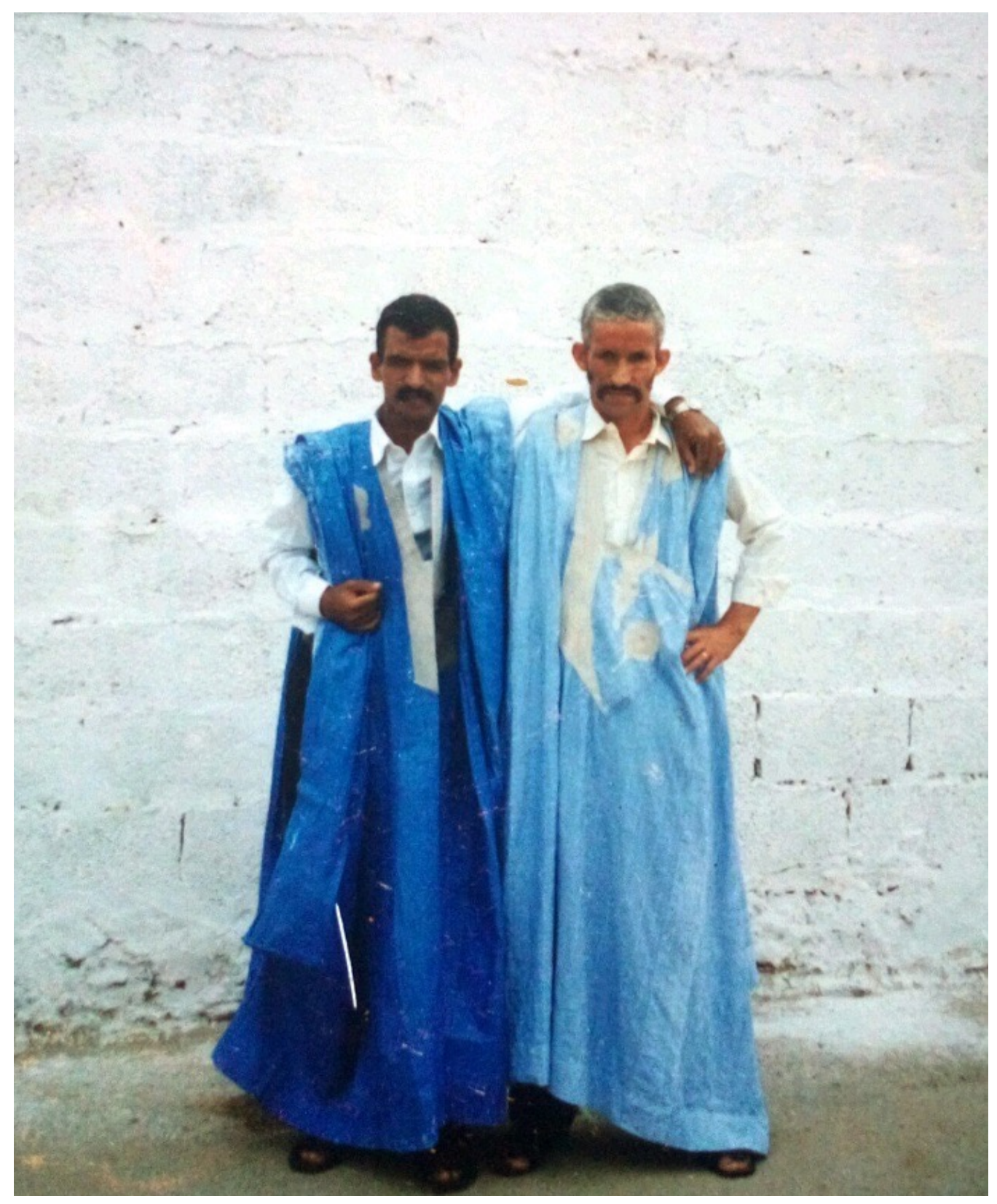

Sid Ahmed Hnini, a la izquierda, en la Cárcel de Agadir, 1994 


\section{Las visitas familiares en prisión}

Mi familia en El Aaiún se enteró a la semana (o pocas semanas) de mi detención. Pero como no hubo comunicación oficial alguna, nadie, en principio, sabía nada de nosotros. ¿Cómo se enteraron? La historia viene de antes de mi detención, gracias a un gesto de gracia que tuvimos con un chico saharaui en una ocasión, que lo pusimos en libertad después de haberlo detenido en el Sáhara. De hecho me encargaron a mí, no sé si en el 78 o el 79, llevarlo hasta Tafudart y dejarlo volver al Sahara. Después de volver a los territorios ocupados se alistó en el ejército marroquí. El día de mi detención estaba él presente. Se me acercó y se me presentó, me dijo que conocía mi casa en El Aaiún y que si tenía alguna documentación comprometida, que se la diera para que la escondiera o destruyera. Yo tenía notas de reconocimiento y una agenda, se las pasé a escondidas. Me dijo "avisaré a tu familia de que te han capturado". Pero no lo hizo por miedo. Aún así se lo contó a algún familiar suyo y este le hizo llegar la noticia a mi padre. Nada más enterarse, mi padre viajó de El Aaiún a Agadir, se alojó en casa de un amigo suyo policía y le contó lo que le había traído hasta allí. Su amigo le dijo que si no le habían notificado oficialmente mi detención, es mejor que se volviera a El Aaiún hasta entonces, “porque si te presentas preguntando por tu hijo, te preguntarán cómo te enteraste y la cosa podría complicarse". Las visitas no llegaron hasta cuatro meses después de nuestra detención. Justo un mes después de exhibirnos como trofeos en la radio y la televisión del enemigo, avisaron a nuestras familias para nos vinieran a visitar en la prisión de Agadir.

La primera persona que iba a visitarnos, Ould Elheirij, era un hombre mayor padre de uno de los detenidos. Lo llamaron y acudió a una oficina a la que iba la gente antes de llamarnos a nosotros. El hombre escuchó cómo hablaban por teléfono y repetían su nombre, "Elheirij, Elheirij, Elheirij", entonces el hombre le dijo a al hijo que lo acompañaba "apúrate, están hablando de mí y no debe de ser algo bueno" y del miedo puso pies en polvorosa y volvió a El Aaiún sin encontrarse con su hijo detenido. La gente estaba aterrorizada, el miedo los paralizaba y los empujaba a ponerse a salvo a la mínima oportunidad. Marruecos sembró el terror en esos años. En el caso de ese hombre, Ould Elheirij, es comprensible por la trágica historia que vivió su familia. Su novia fue detenida embarazada, la llevaron a uno de los centros de detención forzosa de civiles saharauis en Agdiz y Magouna, y el día que dio a luz le quitaron la niña, la devolvieron con su padre y no le dijeron nada de la criatura. No supo nada de ella, si estaba viva o muerta, hasta salir de prisión, dieciséis años después, cuando la encontró hecha una mujer. Es el terror en su máxima expresión. La mayor tortura para un padre o una madre, no saber nada de sus hijos.

Finalmente la primera visita real que tuvimos fue por agosto o septiembre, no puedo recordarlo bien, porque no sabíamos en qué día vivíamos. Claro, no había ni prensa que leer, ni radio que escuchar ni televisión que ver. A uno lo mantenían encerrado en su mazmorra, rodeado de ese hedor tumefacto a 
desinfectante, carcomido por los piojos, mientras el mundo exterior seguía en marcha. De día nos sacaban un cuarto de hora a ver el sol, y a veces menos, sin permitirnos hablar con nadie ni entre nosotros. Por la noche nos llevaban a hacer algunas curas por las heridas de los que iban con bastón o muleta, por las diarreas que provocaba el mal estado de la comida y el agua. Las salidas nocturnas para las pequeñas curas a veces nos ponían en situaciones tragicómicas: en una ocasión coincidimos con unos militares que estaban a nuestro lado, alguno de los guardias les dijo "estos son Polisarios"; casi se les corta la respiración y una dijo "ay mi madre, vámonos de aquí”, entonó una suerte de vade retro Satanás y salieron huyendo sin curarse en la enfermería. ¡Estábamos esposados y con muletas y nos tenían miedo! Ellos creían, según nos contó tiempo después un guardia en la cárcel de Kenitra, que nosotros éramos una especie de monstruos con cuernos, ágiles como las cabras saltarinas que brincan de un lado para otro. Nos imaginaban de todas las maneras menos como personas. El término Polisario traía a su imaginación toda suerte de monstruos mitológicos. Volviendo a las visitas, continuamos recibiéndolas hasta diciembre de 1984, cuando fuimos trasladados a la otra prisión.

\section{De la prisión de Agadir al infierno de Kenitra (diciembre 1984-1993).}

Era una noche gélida de diciembre de 1984. Nos avisaron poco antes del anochecer de que enviásemos a algunos a por velas porque iba a haber un corte de luz. Poco después del anochecer cortaron la luz y nos llamaron de uno en uno, nos vendaron los ojos, nos esposaron y nos subieron a unos camiones. Estábamos encadenados de dos en dos y por cada camión había entre veinte y treinta, más los guardias. Los camiones emprendieron la marcha hacia un destino desconocido para nosotros en ese momento. Estábamos helados de frío, la ropa que llevábamos era muy fina y no abrigaba. Algunos compañeros querían orinar, pero los camiones no pararon, a pesar de haberlo pedido. Siguieron su camino sin detenerse hasta llegar a la prisión de Kenitra, 600 kilómetros después de nuestra salida de Agadir, ya al día siguiente. Nos enteramos de que estábamos en Kenitra tres meses después de nuestra llegada.

La prisión de Kenitra era un antiguo penal construido por Francia, cuando Marruecos era su protectorado, donde se encarcelaba a políticos y activistas de todas las colonias francesas de África. Después de la independencia de Marruecos, la cárcel de Kenitra se convirtió en una prisión militar, en la que estaban encarcelados delincuentes comunes militares, algunos condenados a cadena perpetua o a pena de muerte por asesinatos de oficiales, otros condenados por deserción del ejército. Tiempo después conocimos a algunos que nos confesaron que preferían esa prisión a la guerra contra el Polisario. Desertaban a propósito para ir a prisión.

Una vez en Kenitra, con los ojos vendados y muertos de frío, empezaron a bajarnos. “ ¡Dos fuertes!", gritaban, y entre dos nos llevaban y nos arrojaban en las celdas. La celda era un habitáculo de 
tres metros por dos y medio, tenía una cama de cemento, dos mantas viejas, una especie de saco que hacía de sábana bajera. A los pies de la cama había una letrina, sin canalización adecuada, por lo que era frecuente que se embozaran con mucha frecuencia; no tenía tapa y de ella salían enormes ratas de alcantarilla. Una pesada puerta de hierro, con los bordes bajos oxidados, nos mantenía sellados en el interior de la celda. La celda no tenía ninguna ventilación, salvo unos cinco agujeros en un extremo del techo que permitían penetrar pequeños destellos de luz, insignificantes en medio de aquella oscuridad de la celda. Por la falta de ventilación a uno de los compañeros le dio un ataque de pánico, se estaba asfixiando por el hedor que salía de la letrina cuando cerraron la puerta de la celda, gritó que se ahogaba, que se quedaba sin aire, entonces los guardias le contestaron: "¿y qué has hecho tú con nuestros hermanos, perro?”. Tuvo que aguantar, relajarse y callarse. Acabó acostumbrándose. El clima era húmedo y frío, con lluvia abundante en las estaciones de otoño e invierno. En el suelo de la celda no se podía dejar nada, porque se mojaba enseguida y se echaba a perder. Convivíamos con cucarachas y ratas de alcantarilla, y además éramos pasto de mosquitos, piojos y pulgas chupasangre.

Al cabo de tres meses, cuando nos enteramos de forma no oficial de que estábamos en Kenitra, nos visitó el coronel que dirigía la prisión. Nos preguntó si necesitábamos algo, nos dio uniformes militares más abrigados que los uniformes finos que llevábamos desde Agadir. Fue entonces cuando empezaron a permitirnos salir al patio, dos veces diarias, una por la mañana y otra por la tarde, siempre que hiciera buen tiempo. Esas salidas al patio, en gran parte, dependían de la voluntad de nuestros carceleros y de su humor.

La comida era pésima y siempre estaba en mal estado. Las lentejas y las alubias, que eran los platos más comunes, siempre los traían podridos y carcomidos por los gusanos. La verdura que a veces toca, siempre tenía mal olor y peor sabor, especialmente el nabo, que hasta nuestros días sigo detestando. Un panecito cuadrado nos lo daban para todo el día, y había que dosificarlo para que lleguara a la noche una parte de él. Las cenas eran principalmente pasta. Para beber teníamos una garrafa de cinco litros de agua. La garrafa servía también para tapar el agujero de la letrina, librarnos de su mal olor y disminuir la frecuencia de las visitas habituales de las ratas.

El tabaco era un lujo inalcanzable, salvo cuando algún guardia, en un acto de generosidad, nos alcanzaba algunas colillas, que nosotros dosificábamos para que llegasen al máximo número posible de fumadores: molíamos el tabaco de la colilla, rellenábamos un hueso de pollo que habíamos hecho artesanalmente como pipa, y dábamos unas cuantas caladas antes de pasar la "pipa" al compañero de la celda de al lado. Era una aventura fumar, porque para encenderla había que partir la cerilla en vertical y dividirla en cuatro para que llegara al mayor número posible de fumadores.

Hablar y comunicarse estaba vetado. No podíamos hablar entre nosotros ni con nuestros guardianes. De hecho ellos podían ser castigados si infringían la regla de no hablarnos, y de hecho 
cuando nos traían la comida la dejaban en la puerta, cerraban la celda y se esfumaban hasta el turno de recogida de los platos. Muy de noche entre nosotros nos comunicábamos, pero venían los carceleros y daban golpes a la puerta o nos mandaban a callar. De vez en cuando nos dedicábamos a alborotar ese orden y armábamos jaleo. Impedirnos la comunicación era la peor tortura, prohibirnos hablar entre nosotros, o con terceros, era el mayor maltrato, porque el físico duró poco, ya que al comienzo recibíamos alguna patada o bofetón de oficiales iracundos frustrados con nuestra actitud, pero generalmente no solían maltratarnos físicamente. Esa parte la sufrieron más los civiles saharauis desaparecidos y encarcelados en otras prisiones marroquíes. A nosotros como militares nos dispensaban otro trato y otras formas de maltrato, más psicológicas que físicas. Veinticuatro horas en una celda, durante semanas (y si hay puente de por medio, más tiempo todavía confinados en las celdas), sin poder salir y sin hablar con nadie era la peor tortura. Encima había que estar a las ocho despierto, con las mantas ordenadas y la "cama" hecha. Veinticuatro horas sentado o de pie en la celda, tumbado de vez en cuando, eso era lo más cansado y tortuoso. No hacíamos nada de deporte, por supuesto. Pero entre nosotros buscamos la fórmula para sobrellevar la situación de la mejor manera posible, animarnos y resistir en esa infernal prisión.

\section{Resistencia en el infierno}

En las condiciones en las que estábamos, lo único que nos quedaba para resistir era crear un ambiente y clima propios. Tuvimos que ingeniárnosla para estar a gusto y sentirnos más cómodos. El primer paso fue organizarnos para estudiar. Lo primero que había que buscar eran cuadernos para escribir y lápices. Los encontramos. Alisamos la arena y la convertimos en un cuaderno, luego usamos un palito como lápiz para escribir las lecciones. Uno de los compañeros enseñaba árabe, que era la materia obligatoria para todos, otro enseñaba francés y yo español, las dos opcionales y para quienes las eligieran. Sobre la arena hacíamos las lecciones colectivas, y en las celdas hacíamos los deberes. Cada uno llevaba consigo una pequeña piedra blanca y utilizaba la puerta de hierro para hacer los deberes y repasar. Así fuimos luchando por nuestra formación. Esas fueron lecciones inolvidables y retenemos lo aprendido. En cuestión de higiene, ya que era importantísimo para mantenerse mínimamente bien, recurrimos al ingenio. Para afeitarnos tuvimos que fabricar nuestras propias cuchillas, porque el barbero pasaba muy pocas veces con su máquina de gasoil para raparnos y afeitarnos. Las cuchillas las hicimos de los hierros oxidados que arrancamos de las puertas y conseguimos afeitarnos de forma algo decente. Pero la resistencia no se limitaba sólo a la formación y a la lucha contra el abandono, también había que mantener la resistencia de la identidad propia. 
Por ejemplo, siempre nos negamos a cuadrarnos en el izado de la bandera marroquí, y rechazamos tajantemente cantarle las vivas a su rey, lo que supone un gran delito en Marruecos hasta nuestros días. No era nuestro rey, y nosotros no tenemos rey, y no íbamos a cantarles vivas.

Hubo otra ocasión para reafirmar nuestra identidad. Era el año 1985 y en medio de tanta miseria hubo en una ocasión un cambio repentino en el trato hacia nosotros. Sin explicación alguna, un día nos trajeron té y ascuas de carbón para hacerlo. Llevábamos mucho tiempo sin ver el fuego. Otro gesto fue acercar a un grupo de prisioneros de guerra saharauis detenidos entre 1978 y 1984 y de los que no sabíamos nada a pesar de estar antes que nosotros en Kenitra. Algo no encajaba en medio de tanta generosidad. Preguntamos el motivo y nos dijeron que los marroquíes tenían que votar en referéndum la ratificación del tratado de Oujda entre Marruecos y Libia por el que se había creado la Unión ÁraboAfricana (UAA) entre los dos países, que a los dos años quedó en agua de borrajas y solo sirvió para que Hassan II entregara opositores a Gadafi y este, a cambio, cortara su apoyo a los saharauis. Les respondimos que no, que nosotros no íbamos a votar nada y los marroquíes podían votar lo que quisieran, pero nosotros no lo éramos y no íbamos a votar en ningún referéndum.

El único beneficio que sacamos de esa maniobra marroquí, además del té, era el encuentro con los compañeros prisioneros. Los compañeros tenían buenos contactos con algunos carceleros que conocían desde hacía mucho tiempo y gracias a esa relación empezamos a tener medicamentos e incluso periódicos muy pasados. Le hacíamos un encargo al carcelero y él lo traía, entraba en la celda, metía el periódico debajo de la almohada y antes de salir indicaba con un gesto que lo escondiéramos, pero ¿dónde? Aquí viene otra vez el ingenio. La letrina está fijada sobre un terreno blando, por lo que podíamos cavar un pequeño agujero que servía de escondite, metíamos las cosas en una botella atada con una pequeña cuerda y fijada en una piedra. En los ratos de más tranquilidad, leíamos los periódicos, que a veces son de hace dos meses, pero en la prisión era lo que deseábamos, conocer algo de lo que pasaba en el mundo. La incomunicación era tan absoluta que valía la pena repasar veinte veces el mismo periódico. En esa época éramos setenta prisioneros de guerra saharauis, el último detenido entre nosotros fue en el año 1987, pero los encuentros eran escasos. Una vez un grupo pidió verse con nosotros, les permitieron reunirse con nosotros durante un tiempo, luego cambiaron de opinión y lo prohibieron. En esa época conseguimos un aparato de radio de frecuencia modulada, que lo custodié yo hasta su descubrimiento. Escuchaba las noticias en español y en árabe, y mantenía a los compañeros informados. Esa fue la gran revolución, de la que surgió otra, la creación de una revista. Gracias a esas noticias, nosotros podíamos mantener la resistencia y el ánimo levantado, porque las tácticas del enemigo, cuando siempre ve que fracasan sus negociaciones para hacernos pasar a su bando, recurría a estrategias para minar nuestros ánimos. 
Venían para decirnos cada cierto tiempo que algún dirigente del Polisario había desertado y traicionado, que ya estaba acabado el movimiento de liberación y que lo mejor que podíamos hacer era solicitar el indulto e ir al Sáhara, convertida, según decían, en paraíso y nosotros estábamos tirando nuestra juventud en la cárcel. De hecho cuando sí que desertó el primer dirigente saharaui, Omar Admi, vinieron corriendo para decirnos que el Frente Polisario había dejado de existir. Teníamos siempre la misma respuesta: nosotros somos el Frente Polisario. Ellos creían que estábamos totalmente incomunicados, sin noticias, pero se equivocaron. Como la información era poder, y eso nosotros lo sabíamos, el radiorreceptor nos mantenía al tanto de todo, y yo mismo me encargaba de escribir un resumen de las noticias para pasarlas a los compañeros. Venía un compañero asmático que tenía que pincharse cada noche, y venía aunque no lo necesitara, y recogía el resumen diario que yo había hecho para que hiciera llegar la información a los que estaban al fondo del pabellón. Al cabo de un tiempo, en 1988, nos llegó otro transistor, del que se encargaba otro compañero. Entonces vio la luz Al-Asir (El Prisionero), nuestra revista mensual.

Cuando fundamos la revista Al-Asir, cuyos números fueron secuestrados cuando se descubrió su existencia por el chivatazo de cuatro traidores, teníamos como objetivo difundir la información, ocuparnos de temas concretos en cada sección de la revista. Una vez completada la revista, se distribuía la única copia de cada número para que la vayan leyendo los compañeros, de celda en celda. La revista cumplía con su papel, mantener informados mensualmente a todos los compañeros, hasta que nos delataron los cuatro traidores y la revista fue secuestrada, los dos rediorreceptores confiscados y nos quedamos sin medios. La traición era una hipótesis que manejábamos cuando nos organizamos desde el principio.

\section{Organización propia}

Como prisioneros de guerra, teníamos que mantener una postura única, cumplir con nuestras propias normas y mantener una disciplina, la disciplina del guerrillero. Teníamos elaborado un decálogo normativo de obligado cumplimiento por todos, se llamaba el Documento del Prisionero. Lo seguíamos todos como la base fundamental de nuestra existencia en la prisión, especialmente porque contiene todas las indicaciones necesarias para enfrentarnos al enemigo y a posibles divisiones o conflictos internos, traiciones o cualquier tipo de maniobra. El decálogo no lo puedo recordar ahora con exactitud, pero nos daba las indicaciones que había que seguir ante cualquier eventualidad. Por ejemplo, cómo actuar en caso de traición de algún compañero y qué medidas tomar. En este caso, como efectivamente ocurrió, el documento contemplaba el aislamiento y marginación total del traidor o traidores, se le prohibía a los demás hablar con él, pero no se le niegan los cuidados en caso de ponerse enfermo, ni se le negaba cualquier cosa material en caso de necesitarlo, pero la línea roja era hablar con ellos. En caso de que los 
marroquíes nos trajeran a algún tránsfuga del Frente, como llegó a ocurrir, cuál era la postura, cómo reaccionar ante él, cómo tratar con él y qué había que decirle. Otra hipótesis era en caso de conflicto entre compañeros, lo que pasó efectivamente, qué medidas disciplinarias tomar y cuál era el tipo de castigo. También contemplábamos en el Documento del Prisionero cómo reaccionar en caso de que nos indultaran o amnistiaran sin nuestro consentimiento. Se recogía, también, la hipótesis de una media puesta en libertad como una visita a las zonas ocupadas, que tuvo lugar años después.

De la traición de los cuatro compañeros nos enteramos por el arrepentimiento de uno de ellos, Ahmed Mamay, que nos pasó una carta firmada por los cuatro en la que solicitaban el indulto al rey. Pero el arrepentido se arrepintió y volvió a unirse a ellos. Entonces seguimos las normas del Documento del Prisionero y los marginamos totalmente. Fue cuando hicieron llegar el chivatazo de la prensa, la revista y las dos radios que teníamos. Un día vinieron los guardias, nos ordenaron salir de las celdas, las registraron y se llevaron todos los número de $A l-A$ sir, los periódicos que guardábamos y las radios. Era una pena no haber podido salvar al menos un número de la revista. Porque los aparatos de radio daban igual, pues tiempo después conseguimos otro receptor, cuando se suavizaron un poco las condiciones de prisión en el año 1991.

\section{Las negociaciones con el enemigo}

En el año 91 Marruecos estaba recibiendo presiones externas en distintos frentes, uno de ellos el de las prisiones. Decidió entonces abrir las celdas y casi eliminar las individuales, y así empezamos a vivir en grupo y a compartir espacios. Pero en el año 92, cuando estaban a punto de liberar a los cuatro traidores, nos encerraron de nuevo al resto de compañeros, los sesenta y seis restantes. Esa medida obedecía a una estrategia, la de hacer que viéramos el contraste entre las condiciones de quienes pidieron el indulto y los que rechazaron pedirlo. Y sí, vimos cómo los cuatro podían hacer el té sobre el césped, estar al aire libre, ver el sol, comer de forma sana. Y los sesenta y seis restantes nos pusimos todos enfermos por el estado de la comida, estábamos mal alimentados, todos por el suelo sin apenas poder caminar. Menos uno, que milagrosamente se mantuvo en pie. Pero como siempre, acabamos superponiéndonos a todo.

Un día nos llevaron a todos juntos a un local espacioso y con sillas distribuidas. Allí había una delegación que se presentó como organización humanitaria que venía a visitarnos. Dijeron que lo consiguieron después de haber exigido durante años que les permitieran visitarnos, y que por fin les dieron el permiso tras largos trámites burocráticos. Nos dijeron que les habían dado luz verde para ponernos en libertad, solo teníamos que solicitar el indulto y la noche siguiente estaríamos con los nuestros. Volvió la misma retahíla: el Sáhara ahora es un paraíso verde irreconocible, que ya no se parecía a lo que era, que nuestra juventud la estábamos echando a perder en prisión, que pidiéramos el indulto de 
una vez por todas y seríamos hombres libres. Cuando terminaron, levantamos las manos y pedimos el turno de palabra.

-Tenemos algunas peticiones que hacer -dijimos.

-¿Cuáles son vuestras peticiones?

-Queremos atención sanitaria, mejora en la alimentación, salir al patio a ver el sol, hacer deporte, tener acceso a la prensa y tener correspondencia con nuestras familias.

Dejamos claros dos asuntos: primero, que el indulto lo pedía quien haya cometido un delito y al pedirlo lo reconocía, y nosotros no habíamos cometido ningún delito y que no íbamos a pedir ningún indulto; y segundo, nosotros no queríamos que nos pusieran en libertad en Marruecos, sino que o nos devolvían al Frente Polisario o nos dejaban para siempre en prisión. Cuando terminamos, vieron que estábamos decididos a seguir en la misma postura, se marcharon y no volvieron a aparecer. Tiempo después nos enteramos de que no eran de ninguna organización humanitaria, sino que fueron enviados directamente desde el palacio real para persuadirnos. Pero fracasaron, como siempre.

\section{Vuelta a Agadir en semilibertad}

En 1993 una mañana la prisión de Kenitra se llenó de oficiales del ejército y de coches. Nos sacaron temprano, nos vendaron los ojos, nos esposaron, nos encadenaron unos con otros, nos subieron en camiones y nos llevaron al aeropuerto. Lo supimos cuando el avión despegó. En el avión, uno de esos aviones militares de carga, nos pusieron a todos tumbados boca abajo, y entra cada dos de nosotros había un guardia con una porra en la mano, si se te ocurría levantar la cabeza te caía un porrazo. Cuando el avión tomó altura, un compañero nos confesó después que había pensado que nos iban a hacer lo que hicieron en una ocasión en Smara con un grupo de civiles saharauis: na vez que el avión hubiera tomado la suficiente altura, arrojarnos. Aterrizamos en Agadir, de eso nos enteramos después.

Nos llevaron en coche hasta una nave, nos pusieron a todos en fila cada uno mirando hacia una cama, nos quitaron las vendas y vimos el lugar. Todo nuevo, las mantas a estrenar. Había dátiles y leche en abundancia, té y el material para hacerlo, teteras, bandejas y vasos. El contraste entre de dónde veníamos y el lugar al que llegamos era enorme. El impacto era impresionante. Todo lo habían preparado para intentar producir algún tipo de efecto en nosotros. Para coronar el espectáculo, trajeron un camello para sacrificar y nos pidieron a cuatro para hacerlo. En menos de dos días nuestras condiciones de vida dieron un vuelco. Cuando llegamos a Agadir, en ese momento yo pesaba menos de 40 kilos, y eso que mi estatura es de 1,70. Ahora peso 70 kilos. Estaba raquítico, como los otros compañeros. Nadie estaba en su peso natural. Ese día nos dedicamos a saciarnos de carne, dátiles, leche y té. A lo largo de la semana llegaron las revisiones médicas y demás cuidados sanitarios. También nos llevaron al mercado por 
grupos, para comprarnos ropa nueva, zapatos y relojes. Ropa moderna y harapos tradicionales de ellos, como la chilaba. Y cuando los saharauis ven a alguien trajeado y con corbata, suelen pensar que se trata de un retornado traidor.

Y como detrás de cualquier medida siempre hay algo, empezamos a especular con lo que perseguía esa maniobra: ¿ponernos en libertad sin nuestro consentimiento?, ¿obligarnos a vivir en un lugar en el que no queríamos vivir? Todo era posible con ese régimen. Nuestra confusión estaba en el nivel máximo. Y también nuestra alerta. Un día llamaron a un grupo de compañeros y les dijeron que eligieran la profesión que quisieran y el rango que desearan, de oficial para arriba, ya fuera en la gendarmería, en el ejército, en la policía o en cualquier otro aparato de seguridad. O de periodista o en las minas de Bucraá. Lo daban todo. Los compañeros fueron rotundos: "no queremos nada de vosotros, ponednos en libertad para ir con nuestro pueblo, o dejadnos en prisión”. Volvieron a fracasar. Decidieron experimentar con otra táctica, que nosotros ya habíamos incluido como hipótesis en nuestro Documento del Prisionero: las visitas a las zonas ocupadas.

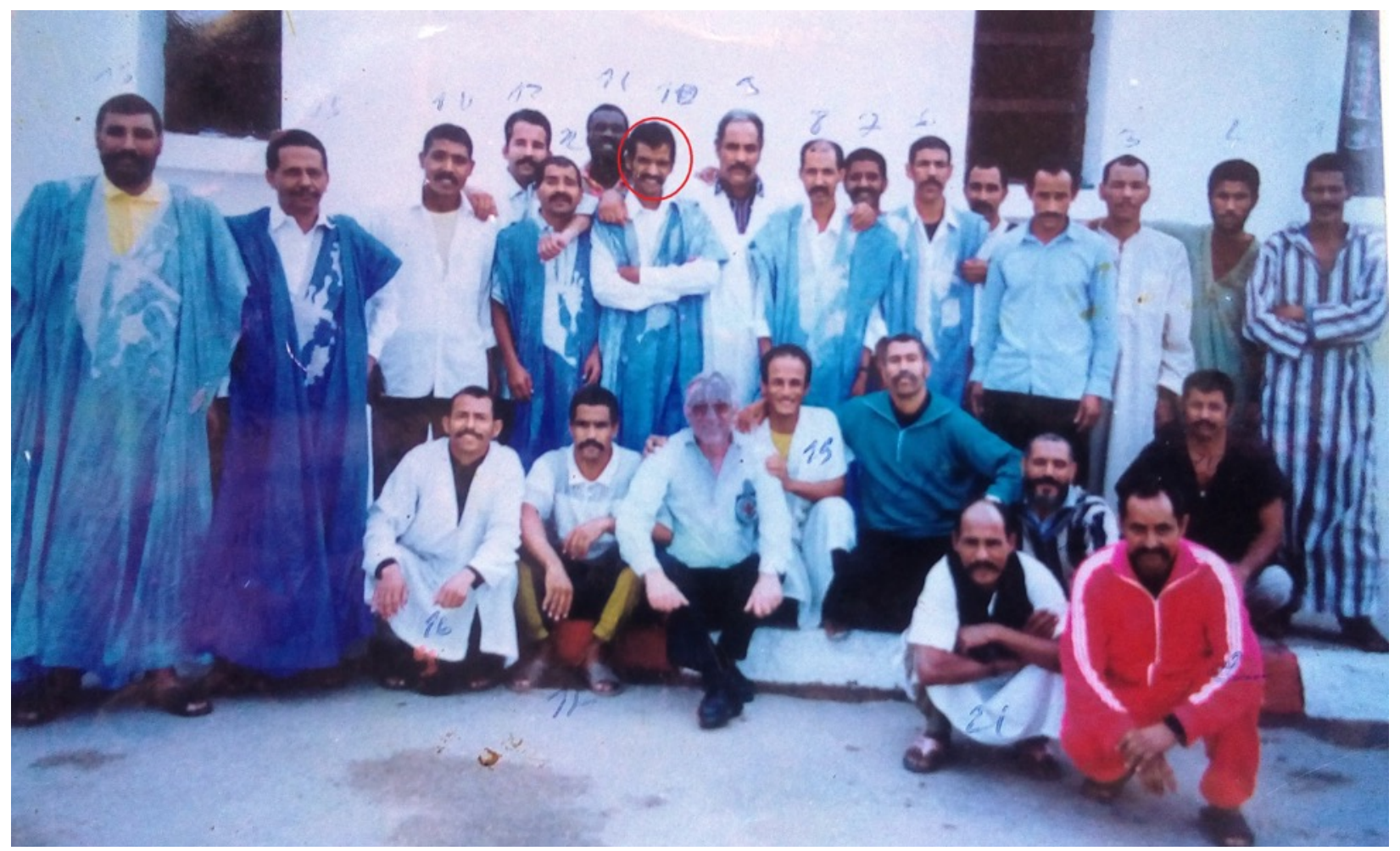

Sid Ahmed Hnini, en el centro. Cárcel de Agadir, 1994 


\section{Visitar la tierra ocupada como chantaje emocional}

Mal les salió la jugada de llevarnos a El Aaiún y Smara de visita. Nos dividieron en grupos para hacer las visitas de forma escalonada. A mí me tocó El Aaiún en la segunda tanda. El caso es que primero se llevaron a un grupo a Smara e intentaron hacerles una fotografía colectiva para conmemorar la visita. Eligieron como fondo un retrato del rey y los compañeros se negaron a hacerse la foto. Los movieron y les hicieron la foto sin el retrato del rey. En El Aaiún, lo que en un principio estaba pensado como visita se convirtió en un peregrinaje de la población. Nos consideraban unos referentes, a pesar de que algunos venían con reservas y se negaban a hablar de política, nosotros les decíamos que éramos combatientes del frente Polisario y no teníamos miedo de nada ni nadie, y que no nos escondíamos, porque lo máximo que podrían hacernos era llevarnos a prisión, en la que todavía estábamos. Continuó el peregrinaje de gente que venía a visitarnos, niños que salían del colegio y venían corriendo para saludarnos, familias enteras, gente desconocida, padres que traían a sus pequeños. La cola parecía una caravana de hormigas. Y dos de los cuatros traidores estaban marginados, nadie los saludaba ni los visitaba, porque nosotros estábamos informando a todo el mundo. La visita iba a ser de una semana, pero al ver el resultado la redujeron a tres días, porque empezaron a circular folletos de propaganda.

Lo más impactante fue cuando me trajeron a mi padre, ya viejo y enfermo, que lo tenían que llevar en una manta porque ya no caminaba. Cuando me lo trajeron mis familiares, todos los compañeros salieron a saludarlo, y ellos les decía "hijos míos, seguid el camino que empezasteis, que los echlouha no son de fiar y no serán nunca aliados”. Los marroquíes aprovecharon para enviarme a un familiar colaboracionista. Me dijo: "mira en qué estado está tu padre, tu madre está enferma, no hay nadie que trabaje en la familia, ya que estás aquí, quédate con ellos” y añadió que mi hermano, que estaba en Las Palmas, iba a venir retornado. Le contesté: “de mi padre me despedí el primer día que empezó la lucha, por convicción mía y suya, fui por unos ideales y continuaré por ellos en la misma senda. Mi padre me querrá siempre que esté en el lugar de la lucha, no aquí. No voy a quedarme aquí”. Intentó por todos los medios persuadirme para que me quedara y abandonara la lucha, buscando encontrar algún punto de debilidad pero no lo encontró. Poco después, cuando aún estábamos en prisión, mi padre falleció. Recuerdo que uno de los compañeros me dijo que si llegan a traerle a su padre en esa misma situación, se quedaría con él. Y sería comprensible, la verdad, porque si te traen a tu padre o a tu madre en esa situación, lo lógico sería quedarse con ellos.

A la vuelta en Agadir, un coronel nos hizo una conferencia. Nos dijo ya habéis visto El Aaiún y Smara, habéis visto cómo han cambiado. Yo levanté la mano y le dije: "a todas las personas que encontramos o tenían un padre, una madre, un hermano, amigo o primo que se murió en vuestras cárceles o fue asesinado". Me dijo que yo era un pesimista. Cuando los marroquíes vieron que ya no 
podían convencernos de ninguna manera, nos trajeron al Comité Internacional de la Cruz Roja. Casi diez años después de nuestra detención enviamos la primera carta a nuestras familias en los campamentos.

Recibimos las primeras fotografías de nuestras familias. Mis dos hijas y mi hijo ya eran casi mayores. Mi hija la mayor tenía ya diecisiete años, mi hijo catorce y la pequeña diez. Estaban todos en una foto con su madre y primos. Dos años después de iniciada la correspondencia, salimos en libertad el 31 de octubre de 1996, hace ahora casi 20 años. En el aeropuerto de Casablanca desfilamos hacia el avión haciendo el signo de la victoria. En los campamentos el recibimiento fue inolvidable. Atrás quedaron mis 12 años de prisión y atrás quedó mi número de prisionero, el 4001. 